\title{
EVALUATING THE MODELS OF SHARIA MICROFINANCE IN INDONESIA: AN ANALYTICAL NETWORK PROCESS (ANP) APPROACH
}

\author{
Euis Amalia \& Mahmudah Atiqah ${ }^{1}$
}

\begin{abstract}
Evaluating The Models of Sharia Microfinance in Indonesia: An Analytical Network Process (ANP) Approach. This study focuses on evaluating the performances of three sharia microfinance models, i.e. cooperative model represented by BMT al Fath, Grameen model represented by MBK, Ltd.co, and mixed model represented by Baytul Amanah Ikhtiar cooperative. ANP approach is used to evaluate the performances of those models from five important aspects (clusters) as the determiners, such as human resource, finance, management, sharia compliance, and marketing. The findings of this research show that the most important aspect (priority) among the clusters is human resource. Thus, the best strategy is the mixed-based; the model which integrates the cooperative system with grameen system. It becomes the best model inasmuch as it implements values of both co ownership and co responsibility, in addition to power of collectivity resulting in no cash collateral.
\end{abstract}

Keywords: Sharia Microfinance, Performance, ANP, Strategy

Abstrak. Evaluasi Model Keuangan Mikro Syariah di Indonesia: Suatu Pendekatan ANP. Fokus dari kajian ini ialah untuk melakukan evaluasi atas tiga model keuangan mikro syariah, yaitu model koperasi yang direpresentasikan oleh BMT Al-Fath, model Grameen yang direpresentasikan oleh MBK, Ltd. co, dan model campuran yang direpresentasikan oleh koperasi Baytul Amanah Ikhtiar. Pendekatan ANP dipergunakan untuk evaluasi atas kinerja dalam model ini pada lima aspek utama yaitu sumber daya manusia, keuangan, manajemen, kepatuhan syariah, dan pemasaran. Temuan dari kajian ini menunjukkan bahwa aspek yang paling penting antar kluster ialah sumber daya manusia, dan strategi terbaik yang dipergunakan strategi campuran, yaitu yang mengintegrasikan sistem koperasi dengan sistem grameen. Hal ini menjadi model yang terbaik untuk diimplementasikan dalam keuangan mikro syariah.

Kata Kunci: keuangan mikro syariah, kinerja, ANP, strategi

First draft: September, 12th 2014, Revision: November, 5th 2014, Accepted: December, $5^{\text {th }}$ 2014

${ }^{1}$ Syarif Hidayatullah State Islamic University. Jl. Ir. H. Juanda No. 95, Ciputat, South Tangerang, Banten, Indonesia.

euis.amalia@uinjkt.ac.id; ach.blue@gmail.com 


\section{Introduction}

Economic activity will not be separated from human life. From the point of view of the jurisprudence science, economic activities not included chapter worships, but muamalah chapter. National economic conditions are still recovering today that have an impact on the difficulty or fear in the form of bank financial institutions for lending, especially for the development of the real sector in small land medium scale. Currently, the most dominating economic problem is poverty. One of the main causes of poverty indeveloping countries is the lack of access to productive capital (Todaro, 2009). Indonesian economy not only face structural imbalances in the acquisition of value-added and employment among sectors but also face the added value inequality between actors or between group scale economic activities and sectors (Amalia, 2008).

Indonesia must find a way out quicly in some strategies, one of them is the reinforcement various aspects of the Micro sector and Small Enterprises (SMEs) which have important role as a major source of employment and income in developing countries (Arsyad, 2008). In addition to proven current global crisis sometimes ago, SMEs present as a solution of the system.

A healthy economy is when the industrial sector little or not at all affected by the global crisis sweeping the world. With this evidence, it is clear that SMEs can be taken into account in increasing competition in the market and stabilization of the existing economic systems in Indonesia. SMEs development is the main priority of the Government in Indonesia (Hill, 2001). Difficulty capital became a major issue in the developmentof SMEs. Community Under almost untouchable (underserved) and it is not considered to have potential funding by formal financial institutions like banks, so it causes an stunted economic acceleration.

One strategy in many countries have grown in overcoming the problems that have been focused on improving access to credit facilities with the establishment of a microfinance institution (MFI) that offer credit to the poor (Haryati, 2007). Alternative financial institutions fund agencies rooted in the midst of a society where the distribution process funds is done in a simple, expensive, and fast with the principle of alignments to small communities and fair (Lestiadi, 2008). Indonesia with various forms of existing MFIs, was expected by the agency can be run in accordance with the expectations. So any type of institutional Microsharia is still varieted, like legal entities and cooperatives around 30 percent are cooperatives or other legal entities are not even incorporated. In connection to this problem the authors need to do research about the model of microfinance institutions in Indonesia, which has opportunities to develop operations with sharia system, both of the financial and non-financial related to the strengthening of the role of business small micro. 


\section{Literature Review}

Microfinance institution is indicated by regulations, innovation, and flexibility designed on the basis of social environment and local economy. Microfinance is a phenomenon, that complicated and dynamic economic and socio-cultural dimensions. The definition is used by Microcredit Summit 1997 and Microcredit Summit in New York 2002 stated that: "programmes extend small loans to very poor for self employment project to generate income, allowing them to care for themselves and their families (Amalia, 2008). Another definition is used by The European Banking Federation stated that microcredit in European Banking Industries refers to small loans and micro entities, and small commercial customer groups (RohmatulAjija, 2010).

Microfinance is committed to serve people ignored by formal banking sector "unbankable". The development of Microfinance sector is based on the assumption that poor people have economic capacity to conduct their own project to get return. But unfortunately, they have limited access to some banking products such as saving accounts, credits, and insurance facilities. World bank predicts that the general condition of market and demands to microfinance come from households and small companies that unregulated operating in informal economic sector. World Bank predicts that potential market for micro credit around the world today is less than 100 million customers.

Table 1. Proportion of Size Business in Indonesia Year 2012

\begin{tabular}{ll}
\hline Category & Number of SMEs (\%) \\
\hline Small and Micro & $94 \%$ \\
Medium & $3 \%$ \\
Large & $3 \%$ \\
\hline
\end{tabular}

Source: Ministry of Cooperation and SMEs, Republic of Indonesia

Based on that data, it is clear that small medium enterprises or SMEs are very potential in economic world. The general condition of informal sectors are often described as an institution that has a limited access to capital. It is owned or managed by a family, which is usually small scale and no legals, is running in unregulated markets that is easy to escape from the market, employs tons of people who usually have lower education and limited skills (Edratna, 2013).

Therefore, it can be classified that SMEs are based on the number of employees, the rate of income, and the size of asset. According to Hubeis (2009), SMEs are defined in many different ways depending on the countries and other aspects.

In general, the Microfinance in Indonesia operates either sharia-based or 
conventional-based model. The sharia-based microfinance is mostly set up in the form of Baitul Maal wa Tamwil (BMT) operating normaly like other Sharia banks. However, it is running legally under the cooperative regulation on the basis of Act No 25 year 1992 about cooperative rules and PP No. 9 year 1995 which rules the saving and credit cooperative businesses. Therefore, BMT has similar products to the ones that Sharia banks have. Yet it is different from the amount of financing that away less than the Sharia banks can provide (Baihaqi, 2000). In Some cases, there is another kind of BMT operating with totally pure cooperative system. All the cooperative terms are used for its products such as basic contribution/deposit, obligatory deposit, and voluntary deposit. This is of course the kind of BMT also runs under the same cooperative regulations. On the other hand, microfinance in Indonesia either conventional or sharia also can operate grameen model under a venture capital company legally running under No.18/PMK 010/2012. Recently, a brand new regulation has just been released in act No. 1 year 2013 about microfinance institutions. It regulates that all microfinance models must have an operation licence from the Financial Services Authority, both in running with cooperative legals or company. Nevertheless, the position of microfinance nowadays in Indonesia is still debatable depending on the interests, needs, motives, and purposes of stakeholders. Consequently, it is not focusing on regulation issue only.

Shariah microfinance institutions appeared in reality as a social business model movement which rapidly develops in Indonesia. There are at least three models of this microfinance; firstly - BMT running with a cooperative model, secondly - microfinance institution operating with a grameen model, and thirdly - the one operating with both cooperative and grameen model, called mixed microfinance model.In practice, those three models operate with shariah principles such as fairness (Amalia, 2008), cooperation (Alma, 2005), transparency (Daniri, 2005), and, universal values such as prohibition of interest, gambling, speculation activities, and other harmfull activities. In operating this microfinance,those institutions are similar to the banks in terms of funding, financing and other kinds of services offered to their customers.

Table 2. The Comparison of Three Sharia Microfinace Models

\begin{tabular}{|c|c|c|c|c|}
\hline \multirow{2}{*}{ No } & \multirow{2}{*}{ Specification } & \multicolumn{3}{|c|}{ Sharia Microfinace Models } \\
\hline & & Grameen & Cooperative & Mixed \\
\hline 1. & Legals & Co. Itd (PT) & Cooperative & Cooperative \\
\hline 2. & Customers & $\begin{array}{l}\text { Financing for } \\
\text { small groups of } \\
\text { poor women }\end{array}$ & $\begin{array}{l}\text { Financing for } \\
\text { individuals } \\
\text { (anyone can be a } \\
\text { member) }\end{array}$ & $\begin{array}{l}\text { Financing for } \\
\text { small groups of } \\
\text { poor women }\end{array}$ \\
\hline
\end{tabular}


Euis Amalia: Evaluating The Models of Sharia Microfinance

\begin{tabular}{|c|c|c|c|c|}
\hline 3. & Products & $\begin{array}{l}\text { Profit Sharing } \\
\text { Financing, No } \\
\text { Saving }\end{array}$ & $\begin{array}{l}\text { Saving and } \\
\text { Financing } \\
\text { Products (using } \\
\text { Cooperative } \\
\text { terminologies) }\end{array}$ & $\begin{array}{l}\text { Saving and } \\
\text { Financing } \\
\text { Products (using } \\
\text { Cooperative } \\
\text { terminologies) }\end{array}$ \\
\hline 4. & $\begin{array}{l}\text { Financing } \\
\text { Purposes }\end{array}$ & $\begin{array}{l}\text { Productive } \\
\text { activities }\end{array}$ & $\begin{array}{l}\text { Productive } \\
\text { activities, } \\
\text { Housing, } \\
\text { Education, } \\
\text { Investment, } \\
\text { others }\end{array}$ & $\begin{array}{l}\text { Productive } \\
\text { activities, } \\
\text { Housing, } \\
\text { Education, } \\
\text { Investment, } \\
\text { others }\end{array}$ \\
\hline 5. & $\begin{array}{l}\text { Transaction } \\
\text { System }\end{array}$ & $\begin{array}{l}\text { Profit Sharing } \\
\text { (mudharabah) }\end{array}$ & $\begin{array}{l}\text { Profit Sharing } \\
\text { (mudharabah- } \\
\text { musyarakah), } \\
\text { Soft Loan } \\
\text { (QardhulHasan), } \\
\text { Sales \&Purchaces } \\
\text { (murabahah), } \\
\text { Lease (Ijarah), } \\
\text { the transfer of } \\
\text { debt (Hiwalah) }\end{array}$ & $\begin{array}{l}\text { Profit Sharing } \\
\text { (mudharabah- } \\
\text { musyarakah), } \\
\text { Soft Loan } \\
\text { (QardhulHasan), } \\
\text { Sales \&Purchaces } \\
\text { (murabahah), } \\
\text { Lease (Ijarah),the } \\
\text { transfer of debt } \\
\text { (Hiwalah). }\end{array}$ \\
\hline 6. & $\begin{array}{l}\text { First Amount } \\
\text { of Financing }\end{array}$ & $\begin{array}{l}\text { Rp. } 500.000- \\
\text { Rp. } 1.000 .000\end{array}$ & $\begin{array}{l}\text { Rp. } 300.000- \\
\text { Rp. } 500.000\end{array}$ & $\begin{array}{l}\text { Rp. } 300.000- \\
\text { Rp. } 500.000\end{array}$ \\
\hline 7. & Mentoring & No & No/Yes & Yes \\
\hline
\end{tabular}

The following are the three models of microfinance, which become the object of research in this paper: first, sharia microfinance as cooperative represented by BMT al Fath. Besides implementing the sharia principles, this model uses special cooperative terms for its products and management. In terms of financing, this model provides the credits to individuals, not groups. Second, Sharia microfinance operating with grameen model.This model which has been succesful in Bangladesh is triggered and led by Muhammad Yunuswho has won an a Nobel awards. The basic principle of Grameen model is financing the small groups particularly groups of lower-income or poor women who have the ability to conduct any productive economic activity. In Indonesia, PT MBK Ventura is one sample that totally adopts this grameen system eventhough it integrates this grameen system with sharia principles. Third, mixed-model microfinance is a combination between cooperative and grameen model. Koperasi Baytul Ikhtiar (BAIK) is a shariah microfinance institution which is implemented this model; on one side, it operates using the terms and management of cooperative. However, it also implements the financing program for small groups of women as it is developed by grameen system.

There are several variables that can be compared between the model of microfinance with grameen system, cooperative model, and mixed model, i.e. legal 
aspects, target of customers, products, size of financing, operation systems or type of financing transaction, first amount of financing, and monitoring programs. Those three models have both differences and similiraties.

Furthermore, in term of performance, any institutionshould have a certain standard as indicators to measure its development and sustainability. This study elaborates some factors that may affect the performance of a microfinance institution, as well as the indicators found for evaluating the models. The factors are human resource, finance (Robbin and Coulter, 2012), management (Robbin and Coulter, 2012), sharia compliance, and marketing, including both spiritual aspect and material aspect.

\section{Methods}

To evaluate and analyze the finding of research, Analytic Network Process (ANP) is used as the study approachment and measurement of some criteria (Ascarya and Cahyono, 2010). The approace will identify and classify three models of sharia microfinance into 5 clusters that each of them has 4 main aspects of category. The criteria of clusters are divided into human resources, finance, management, sharia compliance, and marketing. In human resource, there are have 4 main aspects such as cooperation, solidarity sharia principles knowledge and division of the obligations including the rights of officer and reward for the empoloyee.

In finance cluster, there are source of fund, effiency of cost, rate of late payment or non-performing loan, and financing service. The third cluster is management which has the followingfour main aspects: first, institution; second, standard operating management; third, standard operating procedures; fourth, technology. In the cluster of Sharia Compliance, the 4 main aspects comprise include; collateral type of transactions regulation and product. The last cluster is marketing that consists of these main aspects: first, price; second, communication; third, assistancy of the customers; fourth, quality of the products.

Overall, the tendency of all respondents toward the problems and strategies found in the sharia microfinance institutions can be shown by the value of geometric mean. The degree of rater agreement between respondents in term of problems and strategies can be represented by value or score of Kendall's Coefficient of Concordance (W). The result of each respondent can be found by using the ANP analysis software called "Superdecision". To obtain the desired findings of geometric agreement from all respondents, the data are collected from respondents and later will at first need to beexported to the Microsoft Excel program, calculated, and then imported to the "Superdecision" of ANP Network. The next phase is to 
ensure that all the results are correct by validating every single procedure. At this stage, the concordance of Kendall's Coeffeciency is possible to be calculated to see the aggrement among respondents. Eventually, either the specific interpretation (individuals) or overall interpretation (geometric mean) can obviously be identified and concluded.

Geometric Mean describes the priority of results from respective clusters and criteria or nodes. These results are in the form of the most important priority of others. The calculating the geometric mean is used to find out the individual judgment among respondents and to determine the results of group's evaluation or perception (Rusydiana and Devi, 2010). The questions from respondents will be combined and compared to the form an agreement. Geometric Mean is an average scoring system showing tendencies or certain scores with the following formulation (Ascarya, 2012):

$$
\begin{aligned}
& \mathrm{GMk}=\left(\mathrm{R} 1{ }^{*} \mathrm{R} 2 * \ldots{ }^{*} \mathrm{Rn}\right) 1 \mathrm{~N} \\
& \mathrm{GM}=\text { Geometric Mean } \\
& \mathrm{R}=\text { Responden } \\
& \mathrm{N}=\text { Number ofRespondens }
\end{aligned}
$$

After counting the geometric mean, agreement rater can be calculated. Value of rater agreement as a measure shows asuitable degree among respondents (R1$\mathrm{Rn})$ toward problem in a cluster. The measure formula to get the rater agreement is Kendall's Cofficient of Concordance (W; $0<\mathrm{W}<1$ ). W=1. W=1 which shows the perfect suitability. The next step is finding rater agreements such as, transpose ranking counted by ordering normalized value from the biggest to the smallest and then to sum, to count W. If the score of appraisal $W$ is $1(W=1)$, it means that perception or opinion from respondents is perfect suitability. Nevertheless, when the score $\mathrm{W}$ is 0 or is closed to 0 , it means that there is no suitability among the answers from respondents or more various answer.

\section{Discussion}

Based on the findings of research, it can be concluded that the three models of sharia microfinance institutions (i.e. Sharia Cooperative model, Grameen Model, and Mixed Model) have their own operating systems and prosedures. BMT al Fath and Baytul Amanah Ikhtiar with cooperative legals declare that the ownership and responsibility of the institution belong to all of members, while the Grameen Model of MBK Ventura Ltd.co with corporation legals declares that the ownership and responsibility of the company belong to shareholders.

The following are Geometric Mean scores of respective clusters: 
Table 3. Score of Rater Agreement (W) in All of Clusters of ANP

\begin{tabular}{clc}
\hline No & \multicolumn{1}{c}{ Cluster } & W (rater agreement) \\
\hline 1. & Alternative & 0.40 \\
2. & Criteria & 0.32 \\
3. & Human Resource & 0,612 \\
4. & Finance & 0,27 \\
5. & Management & 0,54 \\
6. & Sharia Compliant & 0,628 \\
7. & Marketing & 0,24 \\
\hline
\end{tabular}

From the aspect of customer target, there are some differences among the three models of this microfinance. BMT al Fath focuses on customers individually, while Baytul Amanah Ikhtiar Cooperative focuses on cutomers not only in individuals but also in groups by providing ample financing for women who have productive businesses or economic activites. However, MBK Ventura Ltd.co, the third model, only focuses on providing some financing to the groups of women.

Priority of supported criteria of the models sharia microfinance can be shown in the picture below:

Figure 1. The Priority of the Problems

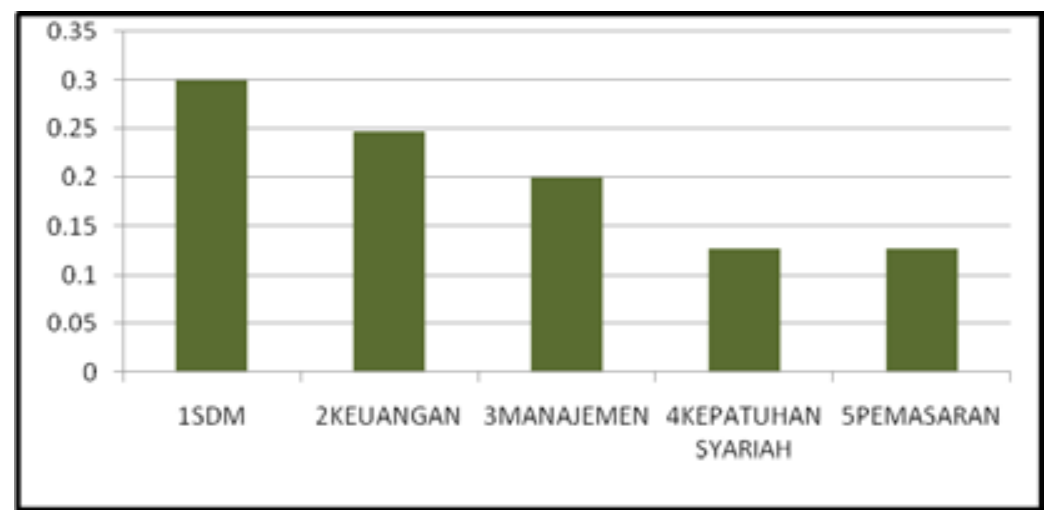

From the aspect of product, both BMT al Fath and BaytulAmanah cooperative offer the same products like saving and financing, yet the latter has additional product namely Qard al Hasan or Benevolent Loan. Unlike the two previously mentioned models, MBK Ventura Ltd.co just provides a financing for customers' businesses under profit sharing principles. In relation with financing products, the first two models also actually provide such services with specific purposes, for example housing, education, and other kinds of investment, besides basic financing. The similarities of all models are that all their financing products apply the sharia- 
based transactions such as profit sharing (mudaharabah and musyarakah), sales (bay' murabahah), and others that embrace sharia principles. In addition, BMT Baytul Ikhtiar and MBK Ventura provide special assistance, guidance, or mentoring for their customers or members.

The highest priority assessment of each respondent on supporting existing criteria on aspects of human resources in accordance with the order of ranking are, the value of human resources geo mean $0.29 ; 0.24$ geo mean financial value; value management geo mean is 0.19 ; sharia compliance and marketing the value of geo mean are the same, namely 0.12 .

In total, the first priority of supported criteria is human resource aspect with rater agreement $W=0.27$. Second, priority of criteria problems is finance, third is management, fourth is shariah compliance, and the fifth is the aspect of marketing.

Figure 2. Priority of Human Resource Problem

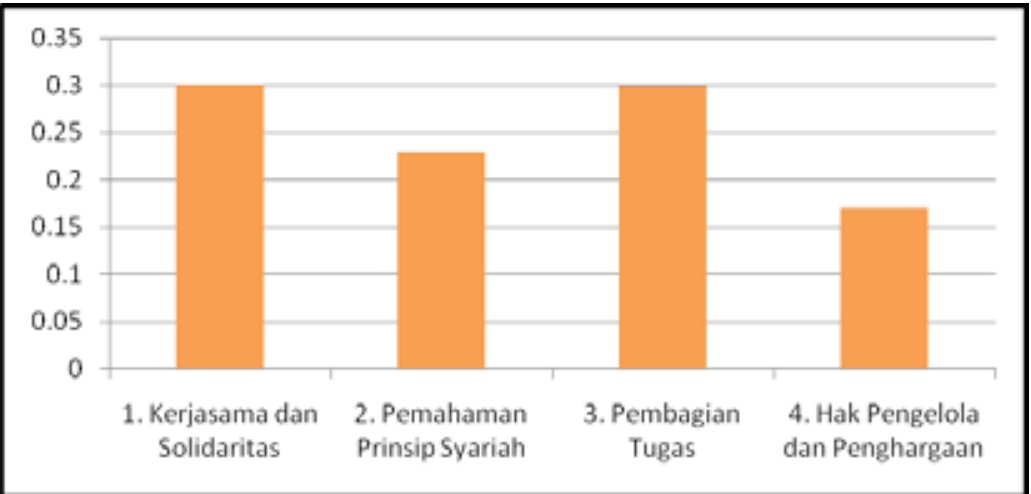

In human resource clusters it has priority value The highest of the assessment of each respondent contained on cooperation and solidarity and division of tasks in order to rank is, the cooperation/team work and solidarity and job description. This value geo mean 0.30 , comprehension Islamic principles geo mean value of 0.22 . Finally rights managers and the award geomean value of 0.17 .The first supporting criterion is human resource. They are cooperation or team work, solidarity, job description according to expert and practicioners with rater agreement $\mathrm{W}=0.612$, in supporting priority in human resource aspect there are two similarities aspects about cooperation and solidarity (Chapra, 2008). The most important value of this rater agreement (W) is team work. It is needed for the sustainability of the institutions as well as the same score in the division of job. In the standardof operational procedures of sharia cooperative services finance models stated that the division of job is important to avoid double burden or double job in one division 
or in one officer than others (SOP KJKS, 2012). According to the experts and praticioners the second priority is human resources or their employee perception of sharia principles. Knowing of officer of microfinance institutions should be best in sharia pinciples knowledge otherwise it influences the institution's reputation and lack of participation of all members. In the last priority is the rights and award for the employees. All employees of the institutions need to receive proper wage or salary for their welfare and prosperity as well as important to give award for the officer or employee who has a good performance or achieve of the targets. This way can be encouraging for themselves and other persons in work and influencing for the creative thinking and skill in marketing strategy.

Figure 3. Priority of Financial Aspect

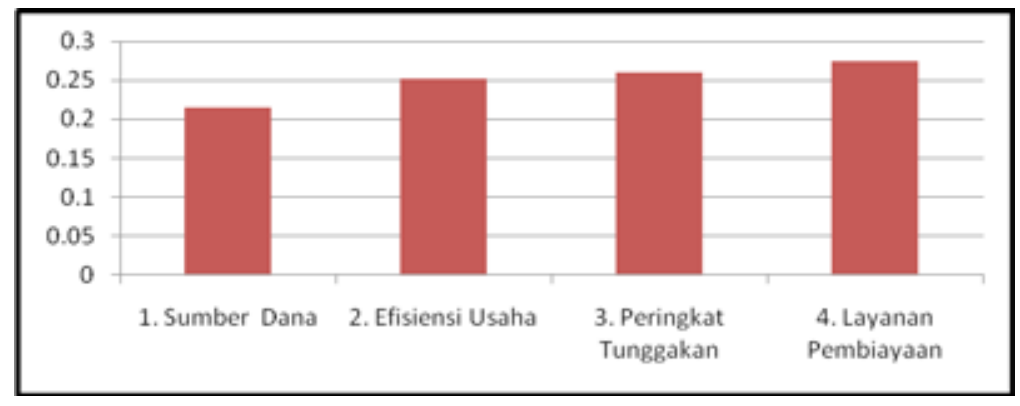

On the financial aspects of the cluster mentioned that the highest priority value to the assessment of each respondent that is found in the service financing in accordance with the order of ranking. The service financing has a value geo mean of 0.27 , the second of the ranking arrears have value geo mean 0.26 , the next order of business efficiency with the value geo mean of 0.25 , and the last of the financial cluster source of funds to have a value of 0.21 geo mean. The first priority criteria of finance in general is service of financing aspect with the rater agreement score of $\mathrm{W}=$ 0.27 . According to Nurmanaf, financing services such as a complex administration in microfinancial institutions cause of users or customers problem to get money soon for their business continuity (Nurmanaf, 2007). Furthermore according to the experts and practitioners the second priority is a number of non-performing loan or performing financing in sharia term. The NPL or NPF needs to reduce continuesly from time to time because of this in a large number make the institutions cannot be running well or stop the operation. The third priority is efficiency of the business activities. Every microfinance institution must have efficient cost including the reduction of expenditure. The last priority is source of fund. It is needed for the institutions to get fund from the external to help the healthty cash condition and make more products to serve for the society as well as customers (Ascarya, 2012). 
Figure 4. Priority Management Elements

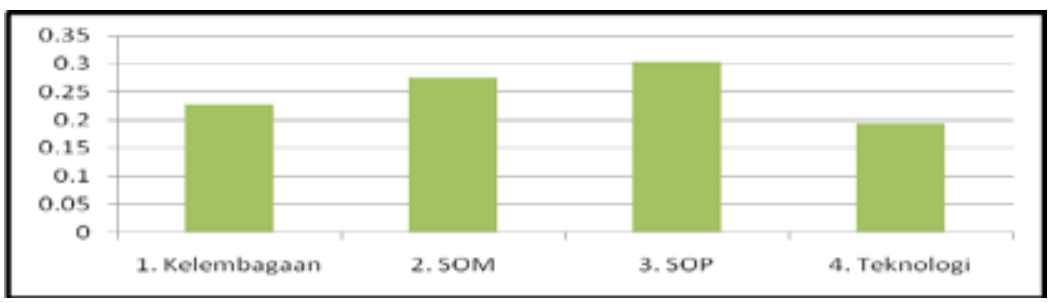

In the cluster management aspects, the highest priority value to the assessment of each respondent is found in the standard operational procedures in accordance with the order of ranking, the standard operating procedure value is 0.30 geo mean, the second order of the operational standards of management geo mean value of 0.27 , next institutional geo mean value of 0.23 , the last of the cluster management technology with a value of 0.19 geo mean. On the management element, the first priority is problem criteria which discusses the aspect of Standard of Operating Procedure (SOP) with rater agreement $\mathrm{W}=0.54$. Exellent and detailed SOP will assist an organization in operation and will be a guide in operating various policies and regulations related to the management of the institution, as described on the Standard of Operating Management (SOM) (SOP KJKS, 2012). Furthermore, practitioners and experts agree that the second priority is Standard of Operating Management (SOM). According to the SOP of Islamic financial services cooperative, SOM is a task structure, working procedures, management systems and standards of work that can be used as a guide for the management to provide good services. The third priority is the institution. An institution with social capital has an enormous influence on the environment. Hence, the institution needs to be strengthened. The last priority is technology. Better technology will make the operations easier and faster.

Figure 5. Priority elements of Sharia Compliance

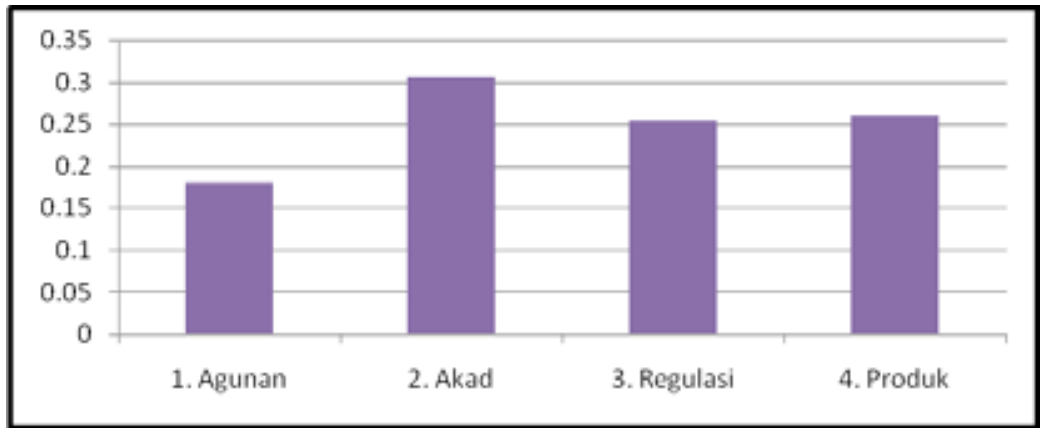


Incompliance aspects of sharia cluster has the highest priority value to the assessment of each respondent that is found in the contract of financial institutions in accordance with the value of the priority ranking order is, on aspects of the contract has a value of 0.30 geo mean, the second order of the views of the product given a value of 0.26 geo mean, the regulation with geo mean value of 0.25 , the last of the collateral cluster sharia compliance with geo mean value of 0.18 . In complying with elements of sharia, the first priority is the ratio of rater agreement contract with $\mathrm{W}$ $=0.628$. Every contract was made by the Islamic microfinance institutions should be based on sharia. The first contract agreed will determine whether it is a sharia or non-Islamic sharia based transaction (Afandi, 2009).

Figure 6. Priority Elements of Marketing

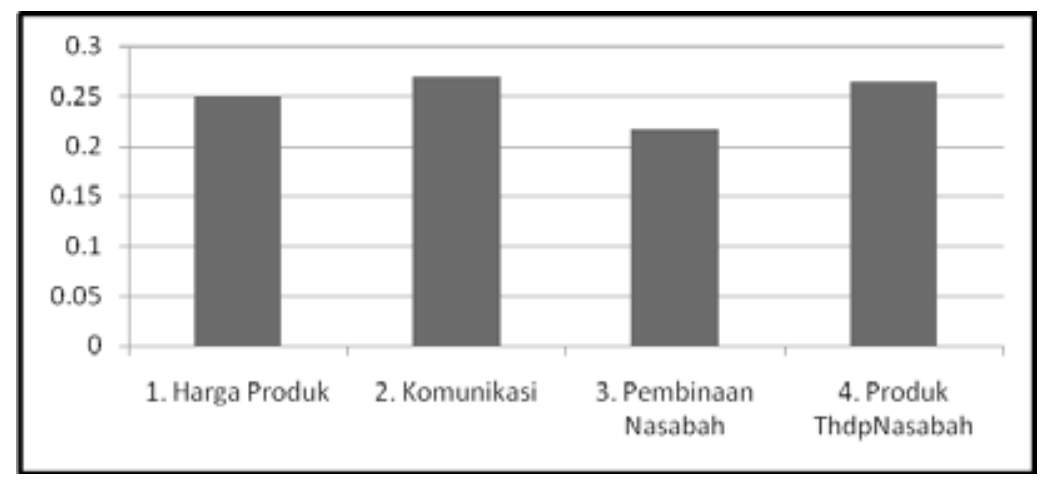

Furthermore, according to practitioners and experts of priorities, the second supporting element is products. The products offered by the Islamic financial institutions must comply with the Shariah aspects and will be supervised by a Shariah Supervisory Board (DPS). The third priority is regulation. A clear legal basis is highly important for an agency to develop and progress more easily (Amalia, 2008). The last priority is the collateral. Angela said that the collateral is burdensome requirements for micro businesses. The absence of collateral in the financing will ease SMEs.

On the cluster marketing aspect, the highest priority value of the respondent is communication. It has a value of 0.27 geo mean, the second order of the views of the product to the customer has a value of 0.26 geo mean, the price of the product geo mean valueof 0.25 , Last of cluster marketing the guidance to customers with value geo mean 0.2.1. The last element is marketing. The top priority lies in the aspect of communication with rater agreement $W=0.24$. Good communication between Islamic microfinance institutions and customers should be maintained. Furthermore, according to practitioners and experts of priorities, there is only a 
slight difference among the priorities. The first priority is product quality that should always be customized by the customers' needs. The third priority is that the price of the product offered must be appropriate and affordable for customers. The last priority is providing guidance especially for clients who have been able to sustain their bussinesses. Supporting the statement, M. Asdar said that customers who have been recruited are not supposed to be left alone running their own businesses by themselves, but they must be fostered in order to keep their businesses running well.

If the overall opinions of experts and practitioners have rater agreement for 0.27 on the aspect of the problem, then their opinions on the aspect of strategy, as a whole, have a rater agreement which is equal to $\mathrm{W}=0.40$ as shown in the figure below:

Figure 7. Priority Elements of Alternatives

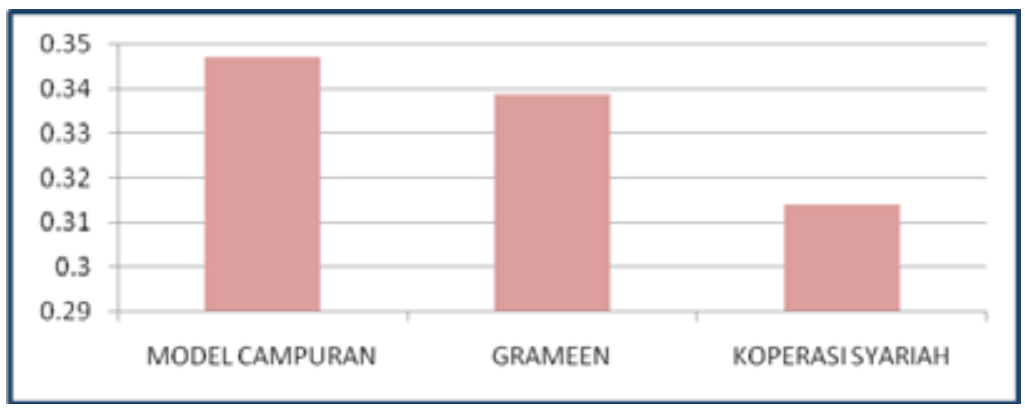

In the alternative cluster has the highest priority value to assessment of each respondent is found in the model agencies Islamic microfinance namely the mixed model, the value corresponding priority with the order of ranking is, the mixed model has value geo mean 0.34 , the second sequence with the Grameen model has value geomean 0.33 , the last node on the cooperative model of sharia with geo mean value of 0.31 . The last priority of strategyis on a model of sharia Islamic microfinance institutions that is cooperative-based. Gaining the rater agreement with $\mathrm{W}=0.40$, those three models (mixed-based, Grameen-based, andcooperativebased) are the models of sharia microfinance institutions, that have been successfully implemented in Indonesia.

Priority of strategy toward thethree models of Islamic microfinance institutions was selected by experts and practitioners as a whole. It puts on the mixed model of Islamic microfinance institutions. The second priority strategy is on the model of Islamic microfinance institutionsthat are Grameen-based. The strategy of the Islamic microfinance institutions that apply mixed model is actually a fairly new system introduced in Indonesia. In fact, the Grameen model has existed for a long 
time in community, especially in Bangladesh. For the very first time, this system was introduced in Bangladesh by Muhammad Yunus. According to Mahmud Toha, the role and effectiveness of the Grameen Bank model have their own appeal in the ease of the procedures and installment loans, relatively low interest rate, and last but not least, the convenience, attention, guidance, and marketing support given to the whole members (Toha, 2000). Consequently, it is more than just cooperative model that has long been in society and that applies the concept of cooperative savings and loans, and more than just the Grameen model that only applies its finance concept.

Microfinance becomes the most important factor in poverty reduction, especially in Indonesia. The number of small and micro enterprises reaches around $99.39 \%$. It is very significant compared to the large and medium-sized businesses. From those data, it can clearly be seen that small and micro enterprises have an important role in the development and the growth of economy, not only in developing countries but also in developed countries. Many institutions provide microfinance services for small enterprises, not only Islamic banking but also followed by many non-bank Islamic financial institutions operating in the micro sectors. Islamic microfinance institutions based on profit and loss sharing or based on sharia is a reality that has been growing rapidly in Indonesia.

In support of the development of Sharia microfinance institutions, the presence of an appropriate model of institution is required for strengthening the micro sector in Indonesia. Based on the findings of research conducted with the approach of the Analytic Network Process (ANP) toward the practitioners and experts of micro enterprises, strategic prioritiesof every element have been identified, namely: first, mixed-based models of Sharia microfinance institutions; second, Grameen-based models of Islamic microfinance institution; and third, models of Islamic microfinance institutions in the form Sharia cooperatives.

The findings of ANP show that the mixed-based model of Islamic microfinance institutions is the most appropriate model to encourage the real sector in Indonesia. The model integrates two systems in operation; sharia cooperative system and Grameensystem (group financing).

Ascarya's research compares microfinance institutions in Indonesia to conventional and sharia types, concludes that the cooperative model like Baitul Maalwa Tamwil (BMT) is a model of Sharia microfinance institution, that can be a sustainable and balanced business which operates as a social institution (Ascarya and Cahyono, 2010). Meanwhile, the research in this paper shows that the mixed model of microfinance institutions embracing sharia system along with its several advantages is the most appropriate alternative model of microfinance institutions to 
be applied in Indonesia, in comparisonto the Grameen model and sharia cooperative model.

Based on the ANP, the mixed-based model of Sharia microfinance institutions is encouraged by various aspects of supporting priorities.

First: Human Resources (HR). The core of rater agreement is (W) $=0.088$ with the first priority elements i.e. cooperation, solidarity, and division of tasks. According to experts and practitioners, human resource is the most important aspect in a microfinance institution because having a strong and good human resource will be a positive influence on the institution, and of course it is supported by good cooperation and solidarity among employeesBased on ANP results, in addition to cooperation and solidarity, the division of tasks between HR has the same level of priority, score of rater agreement $(\mathrm{W})=0.612$. Clear and well organized division of tasks is expected to be able to avoidthe human resources having multiple responsibilities (SOP KJKS, 2012). Human resources should be given responsibilities in accordance with the skills and abilities of each individual.

Second: Finance. The highest priority element that supports the financial aspect is financial services with rater agreement $(\mathrm{W})=0.048$. For instance, a longtime process of administration in a microfinance institution will also make the micro business doers wait for a long time to receive the financing while they are in need of the funds fast (Nurmanaf, 2007). Having a maximum service in providing financing for customers will lead to a positive value of financial institutions.

Third: Management. The highest element of priority in management aspects is the Standard Operating Procedures (SOP) with rater agreement score (W) $=0.54$. Good and detailed SOP will assist an organization to operate and will a guidance to implement the policies and regulations related to the management of the institution, which contains detailed procedures outlined on the Standard Operations Management (SOM) (PINBUK, 2000). The Guidelines containing standard operating procedures within an organization are used to ensure that all decisions and actions, as well as the facilities used in the organization can be efficient, effective, consistent, standardized, and systematic.

Fourth: Sharia Compliance. The highest element of priority that supports sharia compliance aspects is the contract (akad) with rater agreement (W) $=0.628$. The beginning of the contract agreed in the beginning will determine the type of transaction whether it is sharia and non sharia. The purpose of the contract is the pillar of the establishment of a contract so that once the contract is made, the goal is reached.

Fifth: Marketing. The aspect which has the highest supporting priority 
element is communication with rater agreement $(\mathrm{W})=0.24$. Communication can meet the company's goals with the outcomes to be achieved. Communication can function to adapt the changes in the organization as well as the external influences. Communication can also maintain the relationships between members of the organization so that they can perform the task well.

An islamic microfinance institution with BaitulMaalwatamwil model has two products; savings and loans. In contrast, MFIs which is Grameen-based offering only one product is working capital reserved just for women. On the distribution of funding, BMT applies a guarantee for customers who want to have the financing, in contrast to MBK Ventura that does not require any collateral in financing its clients. Instead, MBK implements joint responsibility concept to help each other among groups that do not have the ability to pay.

Thus, the strategic choice based on the ANP approach necessitates the existence of a model of Islamic microfinance institution which applies sharia aspects either in the collection or in the distribution of funding as applied by BMT with the cooperative system. Unfortunately, people still objection to BMT's policy which still applies cash collateral or physical assets as the guarantee for instance, certificates or other sorts of securities.

While in the Grameen system, a group its self is the warranty, which is called as 'collective responsibility', so this system never makes any type of physical assets as the warranty. Facts show that Grameen system has been successful in terms of maximum financial returns with a minimum level of bad loans, almost $0 \%$. Islamic microfinance institutions with a mixed model will be more sustainable with the support of five aspects; human resource that is competent and professional, finance that is accessible and adequate, management which is effective and efficient, sharia compliance that is consistent either in the operational or in the product and marketing that is communicative.

Evaluations conducted on Islamic microfinance institutions Baitul Maal watamwil, gramen models, and mixed models based approach Analytical Network Process (ANP) found that Islamic microfinance institutions have decisive factors in the performance of the supporting activities that, in terms of evaluations conducted on the three models of Islamic microfinance institutions; BMT, Grameen, and mixed model, using the ANP approach explain that the Islamic microfinance institutions have decisive elements which support their performances in five important aspects or clusters. Every single cluster has four elements and indicators as follow: first, elements of human resource cluster are cooperation and solidarity, understanding of Islamic principles, division of duties and responsibilities, and awards. Second, elements of finance cluster are the source of funding, business efficiency, ranking of arrears, 
and financing services. Third, elements of management cluster are institutional matter, standard operating procedures, standard of operational management, and technology. Fourth, elements of Sharia compliance cluster are collateral, contract $(a k a d)$, regulation, and products. Fifth, Elements of marketing cluster are product pricing, communication, coaching, and product quality.

The solution in the development of models of Islamic microfinance institutions for strengthening the real sector in Indonesia is applying a mixed model in its process. Mixed model is a model of Islamic microfinance institution, which implements two systems i.e sharia cooperative system and Grameen system. This mixed model is a good strategy and has a better performance supported by five aspects: first, human resource a support in the area of cooperation and solidarity. Second, finance a support for financing services-. Third, management is a support in the area of standard operating procedure-. Fourth, Shariah compliance is a support in the area of contracts. Fifth, marketing is a support in the area of communication.

\section{Conclusion}

Based on the foundings, it can be concluded that Islamic microfinance institutions with the cooperative model of sharia Baitul Maal wat tamwil, gramen models, and mixed models (combining cooperative model of sharia and gramen) have each system and procedures in operation.

In BMT Al-Fath and BMT Baytul Legal based on cooperative endeavor where responsibility the company is shared. In contrast to MBK Ventura -foundation law based venture limited liability company- where responsibility fully held by shareholders.

Evaluations were conducted on Islamic microfinance institutions Baitul Maalwatamwil, gramen models, and models based on the mixture approach Analytical Network Process (ANP) found that the agency Islamic microfinance has a determining factor in the performance of the supporting activities which, in terms of human resources has four indicators, cooperation and solidarity, understanding of Islamic principles, the division of duties and rights managers and awards. From the financial side have four indicators, namely the source of funding, business efficiency, ranking arrears, financing services. The deciding factor supporting performance the next of the management side, there are four indicators, namely, institutional, standard operating procedures, operational standards, management, and technology. Furthermore, based on adherence factor Shariah is based on indicators of collateral, contract, regulation and products given. Last factors supporting performance in terms of marketing institutions based on product price indicators, communication, coaching customers, and the quality of the product. 
Solutions in the development of a shariah microfinance institutions model to the strengthening ofthe real sector in Indonesia, namely by applying a model mixing the process. Mixed model is a model agency Islamic microfinance that applying two systems in operation. The first system is based on sharia and second cooperative gramen system. Model-based Islamic microfinance institutions have amixture of strategies to support better performance, which is supported based on five aspects of the operation, namely: first, resource human strengthening of the cooperation and solidarity; Second, financial strengthening of the financial services; Third, strengthening management standard operating procedures of the institution; Fourth, compliance sharia of the contract; Fifth, marketing aspects are supported strengthening of the communication.

\section{References}

Baihaqi, A.M. 2007. Guidelines for the Establishment, Development and Supervision toward LKM BMT. Jakarta: LAZNAS BMT.

Alma, B. 2009. Sharia Business Management. Bandung: Alfabeta.

Amalia, Euis. 2008. Policy Reforms for Strengthening Microfinance Institutions and Micro Small Enterprises in Indonesia. (Dissertation Unpublished). Jakarta: UIN Jakarta.

Ascarya \& W. Cahyono. 2010. In Search of Sustainable Conventional and Islamic Microfinance Model for Micro Enterprises. Working paper. Jakarta: Bank Indonesia.

Daniri, A. 2005. Good Corporate Governance: Concept and Its Application in the Context of Indonesia. Jakarta: PT.TriexsTrimacindo.

Edratna. 2013. How can Microfinance Support the Economy of Low Class People?. fromhttp://edratna.wordpress.com. Accessed on May 3, 2013 ,

Fitchett, D.A \& D.Adam. 1992. Informal Finance in Low Income Countries. Boulder: Westview Press.

Hubeis, M. 2009. Small Business Prospects In the Containers of Business Incubator. Jakarta: Ghalia Indonesia.

Robbin, S \& M. Coulter. 2012. Management. New Jersey: Person Education.

RohmatulAjija, S. 2011. The Effectiveness of BaitulMaalwaTamwil in Reducing Poverty. (Thesis Unpublished). Kuala Lumpur: International Islamic University Malaysia.

Tambunan, T. 2002. Small and Medium Enterprises in Indonesia: Some Key Issues. Jakarta: Salemba. 